\title{
R2D2: An effective model to incorporate ICTs in the EFL classroom?
}

R2D2: ¿Un modelo efectivo para incorporar las TIC en el salón de clases de la enseñanza de un idioma extranjero?

\section{Volumen 20, Número 1 \\ Enero - Abril \\ pp. 1-32}

\author{
Cinthya Olivares Garita \\ Verónica Brenes Sánchez \\ Evelyn Valverde Marín
}

\section{Citar este documento según modelo APA}

Olivares Garita, Cinthya; Brenes Sánchez, Verónica y Valverde Marín, Evelyn. (2020). R2D2: An effective model to incorpórate ICTs in the EFL classroom? Revista Actualidades Investigativas en Educación, 20(1), 1-32. Doi. 10.15517/aie.v20i1.40098 


\title{
R2D2: An effective model to incorporate ICTs in the EFL classroom?
} R2D2: ¿Un modelo efectivo para incorporar las TIC en el salón de clases de la enseñanza de un idioma extranjero?

\author{
Cinthya Olivares Garita ${ }^{1}$ \\ Verónica Brenes Sánchez \\ Evelyn Valverde Marín ${ }^{3}$
}

\begin{abstract}
Information and Communication Technologies (ICT) in English language teaching have become effective tools to boost meaningful learning. In an EFL environment, the need to apply a model to incorporate web tools and free apps in the classroom takes prominence for teachers at the university level. The present study is an attempt at determining the effectiveness of the implementation of the Read-Reflect-Display and Do (R2D2) model by Bonk and Zhang (2006) through the design and application of a booklet of activities used by a group of 14 students of the Associate's program in English and 17 students of the Bachelor's degree in English Teaching at Universidad Nacional, Brunca Branch. Due to its nature, this research encompasses a case study with a descriptive scope. The design and implementation will be analyzed through an empirical predictive and retrospective evaluation considering the administration of a teacher and a student questionnaire and a focus group. The instruments were administered to 31 students and 7 teachers. The results of the analysis led to conclude that the model implemented in the booklet of activities proposed was effective to integrate ICTs to the learning process of a second language and, at the same time, innovate with the techniques used to incorporate the didactic strategies in this type of class. In order to safeguard the effectiveness of the R2D2 model, it is worth considering the teacher's interest and willingness to use the technologies involved.
\end{abstract}

Key words: educational technology, english teaching, apps, digital era, ICT

Resumen: Las Tecnologías de la Información y la Comunicación (TIC) en la enseñanza del inglés han llegado a ser herramientas efectivas para promover el aprendizaje significativo. En un ambiente de la enseñanza del inglés como idioma extranjero, la necesidad de aplicar un modelo para incorporar herramientas web y aplicaciones gratuitas en una clase adquiere particular relevancia para los docentes de universidad. El presente estudio intenta determinar la efectividad de la implementación del modelo Leer-Reflexionar-Demostrar y Hacer (R2D2 por sus siglas en inglés) creado por Bonk y Zhang (2006) a través del diseño y aplicación de un folleto con actividades en un grupo de 14 estudiantes de la carrera Diplomado en Inglés y 17 estudiantes de la carrera Enseñanza del Inglés en la Universidad Nacional, Sede Regional Brunca. Debido a su naturaleza, esta investigación es un estudio de caso con un alcance descriptivo. El diseño y la implementación serán analizados mediante una evaluación empírica predictiva y una evaluación retrospectiva tomando en cuenta la aplicación de un cuestionario dirigido a los estudiantes y a los docentes y un grupo focal. Los instrumentos fueron administrados a 31 estudiantes y a siete profesores. Los resultados del análisis concluyeron que el modelo implementado en la guía didáctica propuesta fue efectivo para integrar las TIC al proceso de aprendizaje de una segunda lengua, asimismo se innova con las técnicas usadas para incorporar las estrategias didácticas en este tipo de clase. Es importante considerar como un aspecto clave en la efectividad del modelo que la persona docente tenga interés y disposición por utilizar estas tecnologías.

Palabras clave: tecnología educativa, enseñanza del inglés, aplicaciones, era digital, TIC

\footnotetext{
1 Professor at Universidad Nacional, Costa Rica. She holds a Master's degree in Second Languages and Culture. Currently, she is a doctoral student of the Doctor of Education Program with concentration on Emotional Education from UNINI, Universidad Iberoamericana of Mexico. Dirección electronica: coliga@una.ac.cr ORCID: https://orcid.org/0000-0001-7516-2715

2 Professor at Universidad Nacional, Costa Rica. She holds a Master's degree in teaching from Universidad San Isidro Labrador, Costa Rica. Dirección electronica: veronica.brenes.sanchez@una.ac.cr ORCID: https://orcid.org/0000-0001-9339-6582

${ }^{3}$ Professor at Universidad Nacional, Costa Rica. She obtained a master's degree in teaching from Universidad San Isidro Labrador, Costa Rica. Dirección electronica: evelynvm@una.ac.cr ORCID: https://orcid.org/0000-0001$\underline{6515-7998}$
}

Artículo recibido: 17 de junio, 2019

Enviado a corrección: 17 de octubre, 2019

Aprobado: 2 de diciembre, 2019 


\section{Introduction}

In this growing globalized era, social, cultural and economic sectors have been changing at an unbelievable speed due to the advances in technology. People around the world possess basic knowledge on the manipulation of technological devices. However, the changing world of work and globalization are forcing education and other areas to update their systems.

Currently, children and teenagers are more proficient users when dealing with Information and Communication Technologies (ICTs) than their professors, and students are turning their backs to the classroom environment by substituting it with their laptops or mobiles. Distant education is increasing dramatically giving any person the chance to study. As an illustration, in the United States 5.8 million students were taking some or all courses at a distance in 2014 (Allen, and Seaman, 2016, p. 4). Millennials feel attached to technology since it offers high quality images, colors, videos, audio, interactive games, among others, and when they go to class, they do not feel part of it, and their attention span does not last too much time. However, teachers still need the physical classrooms to continue training students, but it is the teachers' goal and challenge to find ways to catch the learners' attention during the teaching and learning process in the EFL classroom.

For young people, this adjustment is part of their growing process, but for teachers it has represented valuable time spent learning how to make use of the devices until they feel confident with the new gadgets. On this account, researchers, for example Mısırlı (2016), have created new models to incorporate the latest programs or tools to innovate in the class or out of it. Students with Internet access can learn from home whereas other students attend school to have access to technology due to the lack of resources in their families. Sadly, there are schools that do not provide teachers with specialized training on how to incorporate technology in the class, or teachers simply refuse leaving their old methodologies behind. This can impact $21^{\text {st }}$ century learners in a negative way. When there is no technological innovation in the class, printed materials become less attractive for the millennials. In other cases, the activities provided do not follow a structure and diminish students' interests. This technological era forces teachers to constantly look for new ways to contextualize activities.

As a result of these changes, it is necessary to incorporate the use of apps, computers, and cellphones in the EFL class with a set of structured activities based on a model. The researchers created a booklet of activities following the R2D2. The model R2D2 was designed by Bonk and Zhang (2006). The design of this booklet aims to improve the teaching 
and learning process by incorporating ICTs and using the R2D2 model. The set of activities has been created to engage all the students in the class since their multiple intelligences and learning styles are considered and activated. Every activity will either promote meaningful learning or help the students develop new ways to learn. Teachers will have the activities and the apps needed at hand. In case language instructors are afraid of technology, they will have the chance to follow the step by step guide helping them feel comfortable with the proposed material. Probably, in the near future teachers will be motivated to start implementing their own activities after realizing the positive effects derived from the use of the booklet. In addition, the activities could also be adjusted for other levels or topics.

This study was carried out in 2017 at Universidad Nacional, Brunca Branch in Pérez Zeledón Campus. It is located in the southern region of Costa Rica. Students and professors from the Associate's Program in English and the Bachelor's degree in English Teaching participated in this research by making use of the booklet in some of their lessons. The booklet consisted of activities designed according to the R2D2 model. After its implementation, they summarized their insights through a focus group and the administration of a student and a teacher questionnaire. This study will contribute to the teaching and learning process, and it will shed light upon the way technology must be incorporated in the class.

Based on the purpose of this study, the following research questions will guide data collection:

- How was R2D2 used to design the integration of ICT into structured activities in a traditional course?

- How did the suggested implementation of ICT using R2D2 work in an EFL classroom?

- What improvements did teachers suggest for the implementation of the activities?

This study is divided into four main sections. In the literature review, nine subtopics are discussed. In the methodology the design, site selection, participant selection, procedure and the instruments are described. The data analysis provides the results gathered from the questionnaires, and the focus groups. Finally, the conclusions will entail a discussion of the main findings for the purpose of generating reflection and paving the road for further research. 


\section{Literature Review}

\subsection{Information and Communication Technologies (ICTs) in Language Learning and Teaching}

Language instruction is transformed as society shifts itself, and Computer-Aided Language Learning (CALL) has been a key element to this transformation. Computer language learning started to develop in the late 70 s and 80 s, when focused-on-form activities were carried out thanks to the software available at the moment. In the late 80 s, teachers and curriculum developers witnessed a reconstruction of computer language learning methodologies, in which "task-based, project-based, and content-based approaches all sought to integrate learners in authentic environments, and also to integrate the various skills of language learning and use" (Fitzpatrick, 2004, p.17).

Nowadays, Information and Communication Technologies (ICTs) have become necessary pillars in the teaching and learning process, rather than additional tools in the classroom. Actually, ICTs in language learning and teaching provide an innovative way for communication that transcends the classroom's walls in the search for authentic practices to connect with others in a different alternative than the curriculum may provide (Lund, 2004). Learning in the $21^{\text {st }}$ century entails a whole new perspective, in which instruction is not limited to the classroom. Not only does it expand vision of what is out of a specific learning environment, but it also provides more opportunities for students to improve their skills.

\subsection{Technology and the Age Groups}

With the implementation of the ICTs, language learning and teaching have embraced new approaches that must suit young students' needs and abilities. Nevertheless, ICTs do not seem to be restricted to a specific age group; actually, digital non-natives are migrating to this era so that they can keep up with the changes brought by the technological phenomenon. Kubiatko (2013) analyzed the different age groups' perspectives on ITCs by pointing out that, the so-called millennials, "have some typical behaviors which are different from those of the older people regarding the ICT" (p. 1263). However, to understand those behaviors, it is necessary to review the different generations found in today's society.

The U.S Chamber of Commerce (2012) provided a clear view of these age groups (See Table 1). The researchers of this study made the projection of ages to the year 2020. 
Table 1

Generations by age group

\begin{tabular}{lll}
\hline & Born & Age in 2020 \\
\hline GI Generation & $1901-1924$ & $96-119$ \\
\hline Silent Generation & $1925-1946$ & $74-95$ \\
\hline Baby Boom Generation & $1946-1964$ & $56-74$ \\
\hline Generation X & $1965-1979$ & $41-55$ \\
\hline Millennial Generation & $1980-1999$ & $21-40$ \\
\hline Generation Z & $2000-$ & 20 under
\end{tabular}

Source. Adapted from "The Millennial Generation" by The US Chamber of Commerce (2012, p. 2)

Computer-Aided Language Learning (CALL) had its more successful developments in the 80s; therefore, the first two generations ( $G$ land Silent, born from 1901 to 1946) did not have the opportunity to experience it. Baby Boomers, were the first to include technology in their lifestyles, yet not for education. As pioneers, Baby Boomers set the route to the uses of technology for communication.

The next generation - Generation X, had the opportunity to talk on the first cordless phones, watch cable TV, and use the first versions of Microsoft Windows. These and other technological advances gave this generation a more profound digital awareness since they were the first to grow up with computers. This age group was the first to see the early steps of CALL. For example, "as the same time microcomputers were spreading, the random-access laser videodisc brought a new dimension to language learning in the 1980s, the beginnings of multimedia education" (Hubbard, 2009, p.4). Multimedia education later thrived with the implementation of ICTs in the language classroom, embracing millennials and postmillennials' needs and skills.

Generation $Y$ or the Millennial Generation are tech-savvy people who represent a new whole perspective of the world. As Sandeen (2008) remarked, "millennials grew up with computers; they also experienced the rapid adoption of the Internet, cell phone, and other mobile devices. They are a highly networked, connected generation and tend to be completely immersed in technology" (p.11). This means that language students who belong to this group have an urgency to incorporate technology in their learning process. Under this premise, language instruction must be shaped to fulfill students' needs because the truth is that ICTs are here to stay. If millennials request a technological learning environment, the Generation Z demands a whole new approach. Post-Millennials have a high urgency for technological devices such as smartphones and tablets, and Wi-Fi connection is a must. They may even change traditional learning tools such as the dictionary for the latest free-download apps in the mobiles. 


\subsection{Language Teaching and Learning in the $21^{\text {st }}$ Century}

With Information and Communication Technologies (ICTs) era, curriculum developers, teachers, and other professionals in the field have seen the need to adapt the teaching and learning environment. Several researchers such as Becker (2000), Costley (2014), and Lansen-Freeman and Anderson (2011), agree on the assumption that ICTs are here to contribute positively to the process. According to Fitzpatrick's (2004) points of view, ICTs encourage learners' autonomy and independence as well as opportunities for individual forms of learning. They also foster interaction, social skills, and teamwork, provide a quick access to several forms of teaching and learning materials, help teachers to update contents continuously, facilitate feedback and the organization of the learning process, and call for a role change in which students can take on teaching tasks. Based on this viewpoint, ICTs not only promote a student-centered approach in which learners are part of a meaningful learning process, but it also gives opportunities for both teachers and students to broaden the resources available for successful language learning and teaching.

\subsection{Student-Centered Approach}

A student-centered approach has come to play a significant role in the language learning process. Authors such as Collins and O'Brien (2003) defined student-centered instruction in the following way:

Student-centered instruction [SCl] is an instructional approach in which students influence the content, activities, materials, and pace of learning. This learning model places the student (learner) in the center of the learning process. The instructor provides students with opportunities to learn independently and from one another and coaches them in the skills they need to do so effectively. The SCI approach includes such techniques as substituting active learning experiences for lectures, assigning open-ended problems and problems requiring critical or creative thinking that cannot be solved by following text examples, involving students in simulations and role plays, and using self-paced and/or cooperative (team-based) learning. Properly implemented SCI can lead to increased motivation to learn, greater retention of knowledge, deeper understanding, and more positive attitudes towards the subject being taught (p. 339).

As a result, a student-centered methodology advocates an approach that fosters learners' autonomy without leaving aside classroom cooperation. A student-centered approach stimulates the construction of knowledge through creativity and critical thinking, 
motivating students to learn. This approach, along with the incorporation of ICTs, may launch language learners' engagement in and outside the classroom.

\subsection{Meaningful Learning and Students' Motivation}

Meaningful learning, a paramount concept in language instruction, is generated in the language classroom when new concepts are related to pre-existing familiar concepts (Ausubel, as cited in Ballester, 2014). When students create such a link between new and pre-existing concepts, new schemata are presented. If students are actively engaged in creating meaning, the process of learning a language may be facilitated. Meaningful learning is closely related to motivation. Intrinsic motivation is not enough; this is why teachers should provide meaningful experiences to boost learners' motivation.

In this vein, Mullamaa (2010) found that "a well-balanced ITC environment will enable students to feel the above and stay motivated throughout the learning process" (p. 39). Students' interest, participation, and on-task behaviors may also increase due to motivation. Therefore, if ICTs are integrated into the classroom, they may contribute to the meaningfulness of the learning process. However, encouraging meaningful learning implies a commitment for teachers, who should play some specific roles.

\subsection{Teacher's Roles in a Digital Classroom}

Based on the learner-centered approach, the student is the subject rather than the object of the process. Learners have responsibilities to fulfill and they will act and reflect upon their learning styles and preferences (Fitzpatrick, 2004). Language learners, especially those who belong to the millennial and generation $Z$, are empowered and autonomous, and they may prefer a learning environment that reflects their strong personality and interests. Such hypotheses lead to the conclusion that teacher-centered approaches are considered outdated and no longer effective. On the contrary, teachers must serve as facilitators and guide in the process, providing students with meaningful opportunities to learn the language. However, language instructors' job is not limited to guidance; they must be digitally conscious. Teacher preparation for leading a digital classroom is an essential element for success; teacher effectivity in media-rich environments refers to how much the teacher knows about technology and how they use it wisely (Fitzpatrick, 2004).

This means that teachers must migrate to the digital era, embracing the ICTs inside and outside the classroom. In addition, it is known that the new instruction envisions a society that 
manages 21 st century skills such as critical thinking, communication, collaboration, initiative, leadership, ICT literacy, among other competences (Ramey, 2016, para. 3). All these expected qualities take language instructors to a significant inquiry: what materials or strategies should be used to incorporate ICTs in the EFL classroom and achieve the lesson objectives? Material selection must be carried out carefully in order to maximize the learning process.

Before continuing with the discussion about new pedagogies, it is important to analyze the different forms in which teachers can evaluate the meaningfulness of language materials.

\subsection{Predictive Evaluation and Empirical Evaluation}

Lesson planning is integral to teaching, and part of that preparation consists in looking for the most suitable materials to develop a meaningful class. This is known as predictive evaluation, which is followed by a retrospective evaluation in order to determine if the materials selected have worked for the goals set (Ellis, 1997). This implies that material evaluation should not be limited to the lesson planning; it should be a cyclical process that guarantees the selection of the most convenient teaching resources. Ellis (1997) suggested two ways to carry out a predictive evaluation of materials. First, he recommended checking coursebooks evaluations in journals reviewed by experts in the field. His second piece of advice for teachers is to carry out their own reviews using checklists and guidelines available for the task. This second option may help language instructors to contextualize the resources, which is essential in language teaching.

As mentioned before, choosing the most appropriate material is as important as evaluating if such resources served the purposes at which they aimed. This retrospective evaluation may be executed impressionistically, which Ellis (1997) illustrated with this example: "during the course they [teachers] assess whether particular activities 'work' (usually with reference to the enthusiasm and degree of involvement manifested by students), while at the end of the course they make summative judgments of the materials" (p. 37). Although this is the most common form of retrospective evaluation, it is not the only one. Language instructors may find out the real impact of the chosen materials on the learning process by using students' journals or end-of-course questionnaires. This is what Ellis called empirical evaluation. Implementing these data collection methods may result in a more objective perspective of the material outcomes. 
Empirical evaluation is highly recommended by researchers and teachers. However, as Ellis (1997) also pointed out "these methods are less common because they are time consuming" (p.37). To help solve this issue, this author suggested the micro-evaluation, which consists of the evaluation of one specific task. The term task became the protagonist of a more communicative approach for syllabus design in the last decades. Skehan (1996) defined a task as "'an activity in which: meaning is primary; there is some sort of relationship to the real world; task completion has some priority; and the assessment of task performance is in terms of task outcome'" (as cited in Ellis, 1997, p. 38). Therefore, if an empirical evaluation is simplified to task assessment, the burden of material evaluation may be lightened.

Task evaluation is a convenient option not only for retrospective evaluation (after material implementation) but also for predictive evaluation (before the implementation). Vasiljevic (2011), emphasized that

there is no a magic formula that would guarantee that teachers would always be able to identify all the characteristics of a task that may affect students' performance. Formalizing the evaluation procedure, however, makes such a process more systematic and potentially more objective. (p. 5)

This author proposed a model for predictive task evaluation based on task input, outcomes, and cognitive elements in task procedures. To understand this model, it is necessary to understand these three concepts. Nunan (1989) defined input as "the data that form the point of departure for the task"' (as cited in Vasiljevic, 2011, p.5). Vasiljevic (2011) added that input can be verbal such as any kind of texts, non-verbal such as pictures, illustrations, graphs, etc., or a combination of the both -verbal and non-verbal. The second element -the outcomes, is explained on two levels: the surface level, the achievements after the task completion; and the deep level, the learning objective that is expected. Lastly, the third aspect -the procedures, are the activities carried out by students to complete a task. With the appropriate input, clear outcomes and the well-established procedures, teachers may assure the optimization of the class materials.

Creating or adapting materials for language learning is a meticulous process as well. Tasks in language learning are the opportunities for learners to use the language in context. Verbal and nonverbal input could be presented through authentic resources from a YouTube video to a picture taken by students. Outcomes (objectives and achievements) may vary 
depending on the procedures chosen, and they may even expand if ICTs are incorporated in the classroom. To examine the task, Vasiljevic (2011) explained the following:

A verbal task input should be examined in terms of its authenticity, whilst for non-verbal input, possible cultural bias should be taken into consideration. Task outcomes should be examined for their clarity and student targets should be examined both at the surface level and for their expected learning outcomes at a deeper level. An analysis of the underlying teaching objectives should help teachers define their roles and improve classroom interaction. Making evaluation procedures explicit raises teachers' awareness of any factors in the task design that may facilitate or possibly impede task performance and allows them to make the necessary adjustments in order to optimize classroom practice (p. 7).

All in all, the analysis of task input, outcomes, and cognitive elements is pivotal to task completion and language learning success. Contextualization is a key aspect to learning a language. Most textbooks are considered by experts on the field as non-authentic resources, and in most cases, they are not contextualized. Learning cultural differences is important for students, but teachers must be careful with context biased materials. Moreover, the aim of the material must be clear; language instructors must know what students are expected to do and how they are going to carry out such a task. Finally, and going back to the incorporation of ICTs in the classroom, if technology is going to be employed to teach/learn a language, teachers must be digitally aware; they must keep abreast with the latest trends because that is what students crave for.

\subsection{R2D2 Model}

With the emergence of Information and Communication Technologies, learning environments have evolved. The blended classroom and online learning are common phenomena in the $21^{\text {st }}$ century. Therefore, new pedagogical models have come to contribute to this new era of language learning and teaching. Bonk and Zhang (2006) proposed the R2D2 (Read, Reflect, Display and Do), a model for distance education and online learning. This method "is especially important to address the diverse preferences of online learners of varied generations and varied Internet familiarity" (Bonk and Zhang, 2006, p. 249). These authors identified four components to cultivate learning through digital resources in this model. According to Bonk and Zhang (2006), the first quadrant consists of methods to help learners build knowledge by using online lectures and readings, and podcasts, among others. The second element entails using self-examinations, blogs, writing tasks, and portfolios to 
promote reflective skills. The third aspect stimulates visual representations of content through animations, maps, virtual tours and timelines. The fourth and last feature focuses on what students can do with the input given in hands-on procedures which include simulations, reallife scenarios, and contextualized cases. The R2D2 model comes in handy for teachers who want students to develop critical thinking, creativity, and autonomy while embracing students' learning styles and preferences.

\subsection{R2D2 Model Proposal}

This research is the second phase of a previous study carried out in 2016 by the same researchers about the need to consider technological resources in the class to fulfill the demands of the millennials. To integrate ICTs in the class, the researchers designed a booklet with a set of activities based on the R2D2 model, which includes technology, multiple intelligences and learning styles. The second step after its design was its implementation to determine its effectiveness in an EFL classroom. The material implemented covers four activities about the topic Media for one group and other four about Holidays.

This unit offers seven different interactive apps to learn and practice the language through meaningful tasks (See Table 2 and Table 3). The goal is to boost language learning by using the four stages in the model. Each stage allows learners to have an active role in the activities proposed, and the professor is the facilitator, guiding learners on both the use of the apps and the development of the task. Another significant aspect was that learners were able to improve their language skills by reinforcing a micro or macro skill. The apps employed in the tasks must follow the model to achieve its goals. 
Table 2

Activities carried out with first-year students.

\begin{tabular}{|c|c|c|c|c|c|}
\hline $\begin{array}{l}\text { Model } \\
\text { Stage }\end{array}$ & $\begin{array}{c}\text { Macro/ } \\
\text { Micro Skill }\end{array}$ & Learning Activity & $\begin{array}{c}\text { Multiple } \\
\text { Intelligences/ } \\
\text { Learning Styles }\end{array}$ & $\begin{array}{l}\text { Techn } \\
\text { ologica } \\
\text { I tool }\end{array}$ & $\begin{array}{l}\text { Learning } \\
\text { Strategies }\end{array}$ \\
\hline Reading & $\begin{array}{c}\text { Reading/ } \\
\text { Pronunciation }\end{array}$ & $\begin{array}{l}\text { After reading the text "Internet Addiction," } \\
\text { students take the quiz and play in groups } \\
\text { through the app Kahoot. Before answering } \\
\text { and picking answers, students are asked to } \\
\text { read aloud each item. The teacher guides } \\
\text { their correct pronunciation by providing } \\
\text { immediate feedback. }\end{array}$ & $\begin{array}{l}\text { Visual learners } \\
\text { Interpersonal MI }\end{array}$ & Kahoot & $\begin{array}{l}\text { Evaluating } \\
\text { understanding }\end{array}$ \\
\hline Reflecting & $\begin{array}{l}\text { Reading/ } \\
\text { Speaking }\end{array}$ & $\begin{array}{l}\text { After reading seventeen arguments "For or } \\
\text { Against Facebook", students are asked to } \\
\text { use Penzu to keep their reflections digital. } \\
\text { They reflect upon the reading they just } \\
\text { commented. The students keep a journal of } \\
\text { the readings analyzed in class in their } \\
\text { mobile phones and have them at hand for } \\
\text { whatever purpose the teacher decides. One } \\
\text { of the activities can be to give voice to their } \\
\text { reflections by sitting students in pairs, } \\
\text { having them read their reflections and } \\
\text { sharing with the partner. The teacher can } \\
\text { give students a peer assessment form to } \\
\text { provide each student with feedback } \\
\text { (linguistic forms and quality of content) }\end{array}$ & $\begin{array}{l}\text { Linguistic } \\
\text { MI/Visual } \\
\text { Learners } \\
\text { Interpersonal//nt } \\
\text { rapersonal MI }\end{array}$ & Penzu & $\begin{array}{l}\text { Organizing } \\
\text { information }\end{array}$ \\
\hline Displaying & $\begin{array}{l}\text { Grammar/ } \\
\text { Speaking }\end{array}$ & $\begin{array}{l}\text { The teacher types a set of questions before } \\
\text { the class and saves the questions on his/her } \\
\text { cellphone. After studying a grammar topic, } \\
\text { the teacher makes groups of three students. } \\
\text { Once ready, he or she posts the questions } \\
\text { on WhatsApp and tells students to check the } \\
\text { incoming message. Encourage students to } \\
\text { discuss the questions they receive with } \\
\text { other groups and be sure to keep the time. } \\
\text { Students switch groups every three minutes. } \\
\text { Once practice time is over, tell your students } \\
\text { to organize the answers they obtain in a } \\
\text { chart. }\end{array}$ & $\begin{array}{l}\text { Kinesthetic/Inter } \\
\text { personal/Spatial } \\
\text {-visual MI }\end{array}$ & $\begin{array}{c}\text { WhatsA } \\
\text { pp }\end{array}$ & Summarizing \\
\hline Doing & $\begin{array}{l}\text { Listening/ } \\
\text { Speaking/ } \\
\text { Writing }\end{array}$ & $\begin{array}{l}\text { The teacher creates a WhatsApp group with } \\
\text { the students and invites a native speaker to } \\
\text { get part of the group weekly after studying a } \\
\text { topic. } \\
\text { Some activities with this mode: } \\
\text { Allow the English native speaker to ask } \\
\text { questions on a topic studied in class by } \\
\text { recording his or her voice and requesting an } \\
\text { audio or text as an answer. This activity } \\
\text { could be developed once a week on a } \\
\text { specific date. In case it is not possible to find } \\
\text { a native speaker of English, you could invite } \\
\text { another professor the students do not know. } \\
\text { Alternatives: } \\
\text { Group size could produce an overload of } \\
\text { messages and to avoid this, teachers could } \\
\text { create two WhatsApp groups. }\end{array}$ & $\begin{array}{c}\text { Verbal-linguistic } \\
\text { MI }\end{array}$ & $\begin{array}{c}\text { WhatsA } \\
\text { pp }\end{array}$ & $\begin{array}{l}\text { Group } \\
\text { discussions }\end{array}$ \\
\hline
\end{tabular}

Source: Researchers' own creation, 2019 
Table 3

Activities implemented with second-year students. Topic Holidays.

\begin{tabular}{|c|c|c|c|c|c|}
\hline $\begin{array}{l}\text { Model } \\
\text { Stage }\end{array}$ & $\begin{array}{c}\text { Macro/ } \\
\text { Micro Skill }\end{array}$ & Learning Activity & $\begin{array}{l}\text { Multiple } \\
\text { Intelligences/ } \\
\text { Learning } \\
\text { Styles }\end{array}$ & $\begin{array}{l}\text { Technolo } \\
\text { gical tool }\end{array}$ & $\begin{array}{c}\text { Learnin } \\
\mathbf{g} \\
\text { Strateg } \\
\mathbf{y}\end{array}$ \\
\hline Reading & $\begin{array}{l}\text { Speaking/ } \\
\text { Vocabulary }\end{array}$ & $\begin{array}{l}\text { After reading the chapter Film, students } \\
\text { summarize the most important parts of } \\
\text { it by creating a word cloud. They get in } \\
\text { small groups and look for a computer. } \\
\text { After that, they type on the browser } \\
\text { http://tagul.com and follow the } \\
\text { instructions given to create it.The word } \\
\text { cloud must contain keywords from the } \\
\text { chapter. Once ready, they explain to } \\
\text { their classmates the most significant } \\
\text { parts of the chapter with the word cloud } \\
\text { created. }\end{array}$ & $\begin{array}{l}\text { Visual/ } \\
\text { Verbal- } \\
\text { linguistic/ } \\
\text { Interpersonal } \\
\text { MI }\end{array}$ & WordArt & $\begin{array}{l}\text { Using } \\
\text { graphic } \\
\text { organize } \\
\text { rs }\end{array}$ \\
\hline Reflecting & $\begin{array}{l}\text { Listening/ } \\
\text { Speaking/ } \\
\text { Pronunciation }\end{array}$ & $\begin{array}{l}\text { Students get in groups of three, and } \\
\text { simulate they are presenting a radio } \\
\text { show about a movie they have } \\
\text { watched. They reflect on everything } \\
\text { they watched. They can give a } \\
\text { synopsis about the movie, a critique, or } \\
\text { just comment it. They practice the } \\
\text { simulation, and when they are ready, } \\
\text { the learners record a } 2 \text {-minute audio. In } \\
\text { the end, the students play the audio so } \\
\text { that everyone listens to it. }\end{array}$ & $\begin{array}{l}\text { Reflective and } \\
\text { Observational } \\
\text { learners/ } \\
\text { Interpersonal } \\
\text { and Verbal- } \\
\text { linguistic } \\
\text { intelligence }\end{array}$ & $\begin{array}{l}\text { Voice } \\
\text { Recorder }\end{array}$ & $\begin{array}{l}\text { Commu } \\
\text { nicating } \\
\text { with } \\
\text { other } \\
\text { (role } \\
\text { play) }\end{array}$ \\
\hline Displaying & $\begin{array}{l}\text { Listening/ } \\
\text { Speaking/ } \\
\text { Pronunciation }\end{array}$ & $\begin{array}{l}\text { After watching the movie My Big Fat } \\
\text { Greek Wedding, students get in groups } \\
\text { of three and look for a computer. The } \\
\text { learners discuss the cultural differences } \\
\text { between the two families shown in the } \\
\text { movie. Then, they type on their browser } \\
\text { https://www.mindmup.com/ and start } \\
\text { creating a mind map. They explain it to } \\
\text { their classmates. }\end{array}$ & $\begin{array}{l}\text { Interpersonal/ } \\
\text { Spatial-visual } \\
\text { MI }\end{array}$ & Mindmup & Mapping \\
\hline Doing & $\begin{array}{l}\text { Writing/ } \\
\text { Speaking/ } \\
\text { Pronunciation }\end{array}$ & $\begin{array}{l}\text { Based on the topic about holidays, } \\
\text { students write a story about one } \\
\text { holiday using the website Storybird. In } \\
\text { the story, they include: } \\
\text { - Activities during the celebration } \\
\text { - A funny event } \\
\text { - An unexpected ending } \\
\text { Some groups read their stories aloud. }\end{array}$ & $\begin{array}{l}\text { Auditory } \\
\text { learners } \\
\text { Interpersonal } \\
\text { Nerbal- } \\
\text { linguistic MI }\end{array}$ & Storybird & $\begin{array}{l}\text { Brainsto } \\
\text { rming }\end{array}$ \\
\hline
\end{tabular}




\section{Methodology}

\subsection{Design}

This paper, framed as a case study, aims at determining how the R2D2 model was used to incorporate ICTs in the EFL classroom through the implementation of a booklet of activities. Case studies lead to the understanding of unexplored and new phenomena by allowing researchers to do an in-depth analysis of the how and why of current and unique complexities of events, groups of people, institutions and situations (Simons, 2009). The study will be carried out in a population of 31 students and seven teachers through an empirical predictive and retrospective evaluation of the R2D2 model employed in a booklet of activities. In the first phase, researchers will administer a teacher and a student questionnaire; as part of the second phase, researchers will conduct a focus group with students from two different groups at Universidad Nacional in Costa Rica. The scope of this research study is descriptive. According to Gall, Gall and Borg (2007), the goal of descriptive research is "to describe a phenomenon and its characteristics. This research is more concerned with what rather than how or why something has happened" (p. 24).

\subsection{Site Selection}

This study took place in a public state university in Southern Costa Rica. Specifically, the research was conducted in two groups of the bachelor's in English Teaching and the Associate's program in English. Universidad Nacional is one of the five state universities in Costa Rica. It has seven university campuses, and Pérez Zeledón is one of them. This university campus hosts around 1.000 students enrolled in seven different majors.

\subsection{Participant Selection}

This study is based on a non-probability sampling design. On this account, the researchers followed a convenience sampling procedure since participants were readily and easily available (Lumpur, 2016). There were two groups whose responses and impressions were analyzed. One group was composed of 14 students from the Associate's in English taking the course Culture II. The second group was composed of 17 freshman students from the Bachelor's in English Teaching taking the course Integrated English Skills II. Besides these two groups, three professors of both majors filled out the predictive and the retrospective evaluation of the R2D2 model; other four teachers filled out the retrospective evaluation as well. It is worth noting that three of these teachers implemented the activities 
suggested in the R2D2 booklet during the development of the courses Culture II and Integrated English Skills II; the former taught by just one teacher, the latter by two teachers.

\subsection{Data Collection Instruments}

In order to collect the data, the researchers designed the instruments and tested their validity by appealing to a group of experts' opinions on whether the items in every instrument were appropriate and matched to the content and goal indicated in each of them. These experts were three professors of the English Faculty with ample expertise in EFL teaching, from 5 to 15 years of experience. The items that the experts identified as being flawed were improved and kept for the administration phase.

The four instruments designed, tested and administered encompassed two types of evaluations. First, for the empirical predictive evaluation, a teacher questionnaire was constructed; for the retrospective evaluation of the design and implementation of the activities based on the R2D2 model, the researchers administered a teacher questionnaire, and a student questionnaire. Furthermore, a focal group with the two groups of students was conducted in order to record relevant impressions on the implementation of a booklet of activities following the R2D2 model with the integration of ICT in the courses Integrated English II of the Associate's in English and Culture of the Bachelor's in English Teaching.

The first instrument was the predictive evaluation questionnaire. The aim of this questionnaire was to set a priori estimation of task difficulty and possible drawbacks in the tasks that may affect students' performance. It consisted of three parts labeled task input, outcomes clarity, and procedures. Task input included the type of input: verbal or nonverbal. For the second part of this questionnaire, the outcomes clarity was analyzed. This section comprised the surface level and the deep level by which the outcome of a task can be examined. In terms of Vasiljevick (2011), the surface level "describes what it is that learners will have achieved on the completion of the task, and the deep level describes what learning is expected to take place upon task completion" (p. 6). In this sense, the surface level was assessed by posing questions on how well instructions were written, the clarity of the target, students' engagement, difficulty of vocabulary and syntactic structure, the objectives, the kind of input needed to enhance the learners' task performance, the kind of feedback, and the kind of advice needed to enhance the learners' task performance. For the third part of this instrument, the procedures of tasks were scrutinized. There were two dimensions included in this section to evaluate tasks: cognitive load and availability of prior knowledge. The cognitive 
load dimension integrated elements like number of activities, immediacy of the input, and reasoning demands. The availability of prior knowledge entailed whether the task is cognitively simple or complex, and if the availability of prior knowledge affected accuracy, fluency and lexical complexity of the output.

The teacher questionnaire that accounted for the retrospective evaluation comprised one section for the Objectives Model Evaluation (OME) and another one for the Development Model Evaluation (DME) plus two open questions. The aim of the former was to establish to what extent the task fulfills the objective proposed in the beginning. The aim of the latter was to determine the improvement of the task that can be done in the future. In the OME, the purpose (why) and the content (what) were analyzed. In the content section, there were two types of evaluation, student-based evaluation and response-based evaluation. The former dealt with the students' attitudes to the task. Thus, the effectiveness of the task was measured against the extent to which learners enjoyed the task or found it useful. The latter involved an evaluation of the actual outcomes of the task; in this section, the appropriateness, contribution, improvement, and meaningfulness of the tasks were scrutinized.

The third instrument aimed to collect the impressions of all the students from both groups. First, a questionnaire was given to students. The first part of this instrument entailed a summative five-point Likert scale in order to determine the impressions of the students towards the booklet of activities and applications used to teach the topic under study by using the R2D2 model. The established values for this scale were: strongly disagree, disagree, partially agree, agree, strongly agree. In the second part, qualitative information was collected. This part was aimed to elicit very subjective information from the learners as to have them write what they liked or did not like about the apps and some recommendations to use the application more effectively.

As part of the focal group sessions, the researchers used instrument number four to record the general impressions of the students on both the activities developed with the use of applications in each of the stages of the R2D2 model. One of the researchers was in front of the group sitting in a semicircle. As the researcher initiated a dialogue and discussion of the points mentioned, another researcher took notes.

\subsection{Analysis of Data and Interpretation of Results}

The researchers analyzed every segment of the four instruments: the predictive evaluation questionnaire, the retrospective evaluation questionnaires, and the focal group. 
The data gathered from the predictive evaluation instrument was processed per section according to the percentages given to each of the answers yes/no or very much/much/not much. The results will be revealed through the tables displayed. In addition, the information collected from the retrospective evaluation instrument that corresponded to the evaluation of the booklet after its implementation was also analyzed according to the percentages obtained in each of the sections of the questionnaire. The results will be shown through the tables presented below.

Furthermore, the researchers collected valuable information from the second part of the retrospective instrument administered to seven teachers, three of which implemented the activities of the R2D2 booklet. The results were included in the following section in a narrative fashion with examples of the teachers' actual responses. Next, the researchers also gathered qualitative data from the second instrument of the macro evaluation used during the focal group sessions with each group of students. The students' responses concerning the activities performed according to the R2D2 model were grouped by using overarching concepts derived from the students' impressions under two categories: positive and negative opinions. The results of this analysis will be shown in two tables.

\section{Results}

\subsection{Predictive Task Evaluation}

For the predictive evaluation, seven teachers participated using the questionnaire to analyze the material before its implementation. They were given the booklet of activities based on the use of apps and structured according to the R2D2 model. It is worth noting that three of these teachers later implemented the material in their respective courses Culture and Integrated English Skills II. The instrument was split into three sections: Task Input, Outcomes Clarity and Procedures.

\subsubsection{Task Input}

This section was divided into verbal and non-verbal input. For verbal input, $86 \%$ of the teachers reported that the input was authentic and made for ELT. Also, 71\% reported that the input was simplified. The majority of teachers believed that this booklet of activities offer simplified input that may not risk students' comprehension of texts. In this regard, the material seems to offer valuable input for the students' quick and effective internalization of lexicon and structures. 
For the nonverbal input section, a major percentage of teachers reported that learners do not need cultural background to interpret the visual input appropriately. In this sense, comprehension is not influenced by the images selected to illustrate the texts and activities according to teachers. Correspondingly, $43 \%$ of the teachers held that visuals in the material facilitate comprehension very much, but similarly $43 \%$ of these teachers said that that happens in a lesser degree. This finding reveals that the selection of non-verbal input in the form of images must be carefully done. Although the percentage of those teachers believe that the images in the material do not cause miscomprehension, a similar percentage believes that visuals may subtly influence learners' comprehension of the material.

\subsubsection{Outcomes Clarity}

This section of the questionnaire was divided into surface level and deep level. Every teacher was given some criteria about the surface level to choose from "very much", "much" and "not much". Most teachers stated that instructions were well written, the target was clear to the instructor and students, there was neither much difficult vocabulary to the level, nor any difficult syntactic structure and the objectives were clearly defined (See Table 4). Furthermore, the majority of teachers reported that engagement set in very easily through the application of the activities, but a low number of them informed that engagement happened somehow easily, and another minor percentage believed it happened not so easily. The majority of teachers also pointed out that there were not many difficult syntactic structures employed in the material.

Table 4

Criteria for Surface Level.

\begin{tabular}{|c|c|c|c|}
\hline Criteria for Surface Level & $\begin{array}{l}\text { Very } \\
\text { Much }\end{array}$ & Much & $\begin{array}{l}\text { Not } \\
\text { much }\end{array}$ \\
\hline Are instructions well written? & $86 \%$ & $14 \%$ & \\
\hline Is the target clear to the instructor and students? & $86 \%$ & $14 \%$ & \\
\hline Does students' engagement set in easily? & $72 \%$ & $14 \%$ & $14 \%$ \\
\hline Is there any difficult vocabulary to the level? & $14 \%$ & & $86 \%$ \\
\hline Is there any difficult syntactic structure? & $14 \%$ & $14 \%$ & $72 \%$ \\
\hline $\begin{array}{l}\text { Are the objectives (communicative, purely linguistic or } \\
\text { metalinguistic) clearly identified? }\end{array}$ & $86 \%$ & $14 \%$ & \\
\hline
\end{tabular}

For the deep level analysis, teachers were also asked to select "very much", "much" and "not much" according to four different criteria concerning avoidance of excessive talk, kind of input, feedback and advice needed to enhance the learners' task performance. The majority of teachers asserted that the teaching objectives established in the booklet are 
helpful to avoid unnecessary teacher talk, and in deciding the kind of input, advice and feedback (See Table 5).

Table 5

Criteria for Deep Level.

\begin{tabular}{lllc}
\hline Criteria for Deep Level & $\begin{array}{l}\text { Very } \\
\text { Much }\end{array}$ & Much & $\begin{array}{l}\text { Not } \\
\text { much }\end{array}$ \\
\hline $\begin{array}{l}\text { Does the teaching objective help the instructor to avoid excessive } \\
\text { talk? }\end{array}$ & $86 \%$ & & $14 \%$ \\
\hline $\begin{array}{l}\text { Does the teaching objective help to decide the kind of input } \\
\text { needed to enhance the learners' task performance? }\end{array}$ & $72 \%$ & $28 \%$ & \\
\hline $\begin{array}{l}\text { Does the teaching objective help to decide the kind of feedback } \\
\text { needed to enhance the learners' task performance? }\end{array}$ & $58 \%$ & $28 \%$ & $14 \%$ \\
\hline $\begin{array}{l}\text { Does the teaching objective help to decide the kind of advice } \\
\text { needed to enhance the learners' task performance? }\end{array}$ & $72 \%$ & $14 \%$ & $14 \%$ \\
\hline
\end{tabular}

Source: Information taken from the Predictive Task Evaluation Instrument given to seven teachers.

\subsubsection{Procedures}

For this part, the instrument included two subsections: cognitive load and availability of prior knowledge. The former consisted of three elements: number of activities, immediacy and reasoning demands. Concerning the number of activities, the majority of teachers reported that the material mostly relates to multiple-task activities. In Vasiljevic's words (2011), these tasks foster less fluency but more lexically complex output. Although students took time to perform the activities, and then produce, they generated more elaborate output in lexical terms according to the teachers' responses. In addition, all of them agreed that the procedure to perform the activities is one with greater immediacy; namely, that the activities or exercises can be answered by looking at the material (here and now condition). For the majority of teachers, the material also involves a there and then condition; that is to say, it requires students to use their memory to describe a past situation. In this sense, the material challenged the students to use both "here and now" and "there and then" immediacy as well.

According to Robinson (2003), greater immediacy leads to more fluent and less accurate production. On the contrary, tasks that involved "there and then" immediacy, in which the learners had to retrieve information from their memory were conducive to more accurate and lexically complex production. Regarding reasoning demands, all of the teachers asserted that the activities with the applications used in the R2D2 model more than giving simple information, they require reasoning skills.

The second subsection dealt with availability of prior knowledge. Just $57 \%$ of the teachers believed that the tasks were cognitively simple; $43 \%$ of the teachers thought the activities were not cognitively simple. The finding revealed that the activities of the R2D2 
model expose students to a balance between cognitively complex and simple tasks. On this note, Robinson (2003) stated that 'the high cognitive demands of the task stretch learners' interlanguage, leading to a more elaborate processing of input, better identification of problematic forms in the output, and as a result, greater uptake and longer retention of input" (p.66). On this same note, $86 \%$ of the teachers surveyed reported that students require enough background knowledge to produce orally more effectively and more fluently (See Table 6). Added to this, the majority of these teachers considered that the availability of prior knowledge might affect the output in terms of the lexicon used.

\section{Table 6}

Criteria for Availability of Prior Knowledge.

\begin{tabular}{lllll}
\hline Criteria for Availability of Prior Knowledge & \multicolumn{1}{l}{$\begin{array}{l}\text { Very } \\
\text { Much }\end{array}$} & Much & $\begin{array}{l}\text { Not } \\
\text { much }\end{array}$ \\
$\begin{array}{l}\text { Does the availability of prior knowledge affect the accuracy of the } \\
\text { output? }\end{array}$ & $14 \%$ & $72 \%$ & $14 \%$ \\
\hline $\begin{array}{l}\text { Does the availability of prior knowledge affect the fluency of the } \\
\text { output? }\end{array}$ & $14 \%$ & $72 \%$ & $14 \%$ \\
\hline $\begin{array}{l}\text { Does the availability of prior knowledge affect the lexical } \\
\text { complexity of the output? }\end{array}$ & $72 \%$ & $28 \%$ & \\
\hline
\end{tabular}

Source: Information taken from the Predictive Task Evaluation Instrument given to seven teachers.

\subsection{Retrospective Task Evaluation}

The retrospective task evaluation instrument was divided into an Objectives Model Evaluation (OME) and Development Model Evaluation (DME) section. Three teachers, who implemented the application-based activities through the R2D2 model, filled out this questionnaire. The OME was subdivided into Purpose and Content. Regarding the Purpose section, all of the teachers agreed that the aims were stated in the material; the material did what it said it was meant to do, and the task met its objective. The Content section entailed a student-based evaluation and a response-based evaluation. Concerning the former, $100 \%$ of the teachers reported that the students found the tasks enjoyable and useful. Relating to the latter, all of the teachers reported that the students' reactions towards the material were positive, the material was accurate in terms of grammar, and in terms of the time spent for language used and gained, the time planned for the implementation of the material was sufficient, and the instructions were clear enough. Furthermore, all teachers surveyed indicated that the instructions do not need to be altered or added, and it was not necessary to make any extra language available. 
For the DME, the researchers included four sections: appropriateness, contribution, improvement and meaningfulness. All of the teachers consented that the material was suitable for the targeted learners, the learners were optimistic about the contribution of the material to learning English; it is worth using again, and worth sharing with colleagues. All of them agreed that the material did not need to be improved. $67 \%$ of the teachers affirmed that the material had an impact on the students' learning, and 33\% reported not much. Additionally, $67 \%$ of the teachers reported that what they learned was useful in real life. Just $33 \%$ stated that it was very useful in real life.

For the open section of this instrument, the teachers answered two questions. The first question dealt with the ways the material worked or not worked. A teacher reported that the material used to implement the R2D2 model worked to expand knowledge on a unit that was already studied. The second teacher reported that "the students showed excitement towards the activities, they were really happy interacting with the native speakers of English, and that all students could use the apps easily" (Personal Communication, October 2017). The third teacher informed that the activities were interesting, very useful and enjoyable. The second question elicited information about modifications to improve the effectiveness of the material. One of the teachers answered that in the activity with Penzu, she would change the vocabulary given and useful expressions; the vocabulary was more for speaking than for writing. The second and third teacher said that they would not modify anything, for it worked well.

\subsection{Analyses of the Focal Groups}

The researchers met with the two groups of students who used the activities designed following the R2D2 model on two different dates. The researchers followed a protocol of procedures to elicit valuable information from the students regarding their impressions and opinions about the activities implemented through the use of different technological applications following the model under study. For this purpose, students gathered up in a classroom with two of the researchers. Each focal group on a separate date. The researches greeted, introduced themselves and presented the R2D2 model by sticking some images of the logos of the applications used on the board. Then, researches and the students started a discussion on the activities performed with each application. As the students reacted towards the questions prompted by one of the researchers, the other researcher took notes. Later, students filled out a short questionnaire. 
During the first session, the first focal group was encouraged to give their impressions about the activities developed with the applications Kahoot, Penzu, WhatsApp in the different stages of the R2D2 model: Reading, Reflecting, Displaying and Doing. Although all of the applications scored high according to the group of students taking the course Integrated English Skills II, the most seemingly difficult application to use with the topic Media was WhatsApp during the Displaying stage of the model (See Table 7). Students stated that they were receiving many messages that they could not read at all, and that following the string of the conversation was tiring. However, the activity developed by the use of WhatsApp during the Doing stage was the easiest to do according to students. They reported that communicating with the native speaker was fast and effective by using the application. Furthermore, students faced some setbacks to achieve the goal of the activity done with the use of WhatsApp during the Displaying stage. The students informed that not all of them felt comfortable talking to a native speaker.

\section{Table 7}

Analyses of the Activities of the R2D2 Implemented in the Course Integrated English Skills II with the topic Media.

\begin{tabular}{lllll}
\hline & $\begin{array}{l}\text { Kahoot } \\
\text { (Reading) }\end{array}$ & $\begin{array}{l}\text { Penzu } \\
\text { (Reflecting) }\end{array}$ & $\begin{array}{l}\text { WhatsApp } \\
\text { (Displayin } \\
\text { g) }\end{array}$ & $\begin{array}{l}\text { WhatsApp } \\
\text { (Doing) }\end{array}$ \\
\hline $\begin{array}{l}\text { Was this app easy to use with the } \\
\text { topic about Holidays? }\end{array}$ & 4,8 & 4,6 & 4,2 & 4,9 \\
\hline $\begin{array}{l}\text { Did the app help me achieve the } \\
\text { goal of the activities easily? }\end{array}$ & 4,6 & 4,5 & 3,7 & 4,7 \\
\hline $\begin{array}{l}\text { Were the activities developed } \\
\text { through this app innovative? }\end{array}$ & 4,7 & 4,4 & 3,7 & 4,2 \\
\hline $\begin{array}{l}\text { Were the activities developed } 4,8 \\
\text { through this app useful? }\end{array}$ & 4,6 & 3,7 & 4,6 \\
\hline $\begin{array}{l}\text { Did the activities designed and } 4,4 \\
\text { implemented through the app } \\
\text { respond to my needs regarding the } \\
\text { mastery of the content of the } \\
\text { course? }\end{array}$ & 4,2 & 3,2 & 4,1 \\
\hline $\begin{array}{l}\text { Did the activities designed help me } \\
\text { improve the command of the }\end{array}$ & & & \\
language? & 4,6 & 4,4 & 4,5 \\
\hline $\begin{array}{l}\text { Did the activities designed boost } 4,7 \\
\text { cooperation? }\end{array}$ & 4 & 3,6 & 4,4 \\
\hline
\end{tabular}

Source: Information taken from the Focal Group Instrument given to students.

The most innovative and useful activities that students reported were the ones done through the application Kahoot followed by Penzu. They stated that Kahoot, when used for reading activities, makes this skill fun and exciting. Although using it was difficult at the beginning of the process, it was said to be challenging, competitive, and creative. Penzu was 
thought as a creative application since students found a way to "go green" by saving paper. They wrote their diary entries in their cellphones.

On the contrary, the activity developed through WhatsApp for the Displaying stage was reported to be somehow innovative and useful, but still it scored an average mean. During the discussion held with the researchers, the students asserted that doing the activity through WhatsApp and involving a native speaker was really an innovative task to do. They were aware that WhatsApp could be used for purposes that are more educational. Still, the activities developed through the application Kahoot helped students achieve mastery of the content about Holidays and improve the command of the language. Considering that the activity implemented through the application implied competition, students studied the reading a lot to win when playing with their teams. This feature of the application promoted concentration and interest in the reading. On the other hand, the activity developed through WhatsApp in the Displaying stage scored the lowest in this regard. A small number of students reported that the native speaker returned some of the messages a little later, or it was hard for her to reply to some of them; this made feedback difficult to be delivered. Concerning cooperation, the application that boosted this competence the most was Kahoot in the Reading stage followed by WhatsApp in the Doing stage. The students worked together as a team to compete and win while performing the Kahoot activity. The application fosters engagement and teamwork skills.

The second focal group was carried out with the students from the Associate's program, specifically those taking the course Culture II about the topic Holidays. They were encouraged to provide their insights and impressions about the activities developed with the applications Mindmup, Voice Recorder, Tagul, and Storybird through the different stages of the R2D2 model. The same protocol for the first focal group was employed for the implementation of this second focal group. All the applications used to develop the activities of this model were given a high score (See Table 8). Students of this focal group seemed to enjoy the applications used to develop the activities in the booklet. The easiest applications to use for the students were the Voice Recorder and the Storybird. Both were said to be userfriendly. The Voice Recorder could be used whenever and wherever. The Storybird was easy to handle. 
Table 8

Analyses of the Activities of the R2D2

Implemented in the Course Culture II with the topic Holidays.

\begin{tabular}{|c|c|c|c|c|}
\hline & $\begin{array}{l}\text { Mindmup } \\
\text { (Reading) }\end{array}$ & $\begin{array}{l}\text { Voice Recorder } \\
\text { (Reflecting) }\end{array}$ & $\begin{array}{l}\text { Tagul } \\
\text { (Displayin } \\
\text { g) }\end{array}$ & $\begin{array}{l}\text { Storybird } \\
\text { (Doing) }\end{array}$ \\
\hline $\begin{array}{l}\text { Was this app easy to use with the } \\
\text { topic about Holidays? }\end{array}$ & 3,9 & 4,14 & 3,9 & 4,2 \\
\hline $\begin{array}{l}\text { Did the app help me achieve the } \\
\text { goal of the activities easily? }\end{array}$ & 4 & 4,5 & 4,3 & 4,14 \\
\hline $\begin{array}{l}\text { Were the activities developed } \\
\text { through this app innovative? }\end{array}$ & 4,4 & 4,57 & 4,2 & 4,78 \\
\hline $\begin{array}{l}\text { Were the activities developed } \\
\text { through this app useful? }\end{array}$ & 4,2 & 4 & 4,3 & 3,7 \\
\hline $\begin{array}{l}\text { Did the activities designed and } \\
\text { implemented through the app } \\
\text { respond to my needs regarding the } \\
\text { mastery of the content of the } \\
\text { course? }\end{array}$ & 4 & 3,7 & 4,14 & 3,8 \\
\hline $\begin{array}{l}\text { Did the activities designed help me } \\
\text { improve the command of the } \\
\text { language? }\end{array}$ & 4,14 & 4,3 & 4 & 3,9 \\
\hline $\begin{array}{l}\text { Did the activities designed boost } \\
\text { cooperation? }\end{array}$ & 4,2 & 4,5 & 4,4 & 4,2 \\
\hline
\end{tabular}

Source: Information taken from the Focal Group Instrument given to students.

For the second aspect surveyed in the instrument, the students stated that Voice Recorder was the one that facilitated the achievement of the goal of the activity the most. They reported that they had fun creating the radio show, listening to their voices, even including songs. In this regard, the application Mindmup had the lowest score. Students informed that at the beginning of the process, the app was very difficult to use; but, once they practiced enough, it became easy to use. The activities performed by using Storybird obtained the highest score about innovation, but it was also acknowledged as the least useful. This application helped students retain aspects of the topic that they recently studied, promoted interaction among the students, facilitated learning through the association of the pictures with the words, and helped brainstorm details about the information studied; nevertheless, students reported that the images they needed to compose the story were not enough, and one student considered the application childish. The activity developed through the application Tagul scored the lowest regarding innovation. Some students reported that it was difficult to use at the beginning of the process, it took too much time, and Internet connectivity affected the development of the activity.

According to some students' opinions, the activity implemented through Voice Recorder somehow prevented them from mastering the topic on Holidays. They said they did 
not like being recorded and hearing their voices. On the other hand, the activity developed through the app Tagul allowed the majority of students to grasp the gist of the content better. They could review and make connections of images with words through the app and found it interesting to summarize ideas and demonstrate their creativity. Concerning the last two aspects surveyed with this instrument, the activities developed through Voice Recorder were acknowledged to help students command of the language and boost cooperation the most. As students planned a synopsis of the movie, they checked their grammar and pronunciation several times until they felt ready to record. Students had plenty of time to rehearse the radio show and be aware of each member's role in the group. Some students reported that this activity was one of the best, for they enjoyed creating the script of the show. Other students reported that while they were creating the synopsis, they could have an opportunity to share ideas with the partners. Although all the activities developed through the applications scored high on the aspect about cooperation, the activities that promoted less cooperation according to students were both Mindmup and Storybird. Relating to the activity performed with the application Mindmup, students gave it the lowest score regarding the facilitation of language command. Some students reported that the difficulty at the beginning discouraged them from using the application.

As the students from both focal groups reacted towards the questions prompted by one of the researchers, general opinions and impressions were recorded by the other researcher present at the moment (See Table 9 and Table 10). The students' impressions about each activity done using the different applications were grouped for the analyses in overarching concepts derived from the students' answers. All of the applications employed to perform the activities of the R2D2 model received more positive remarks than negative ones. 
Table 9

Integrated English Skills II Class.

Topic Media.

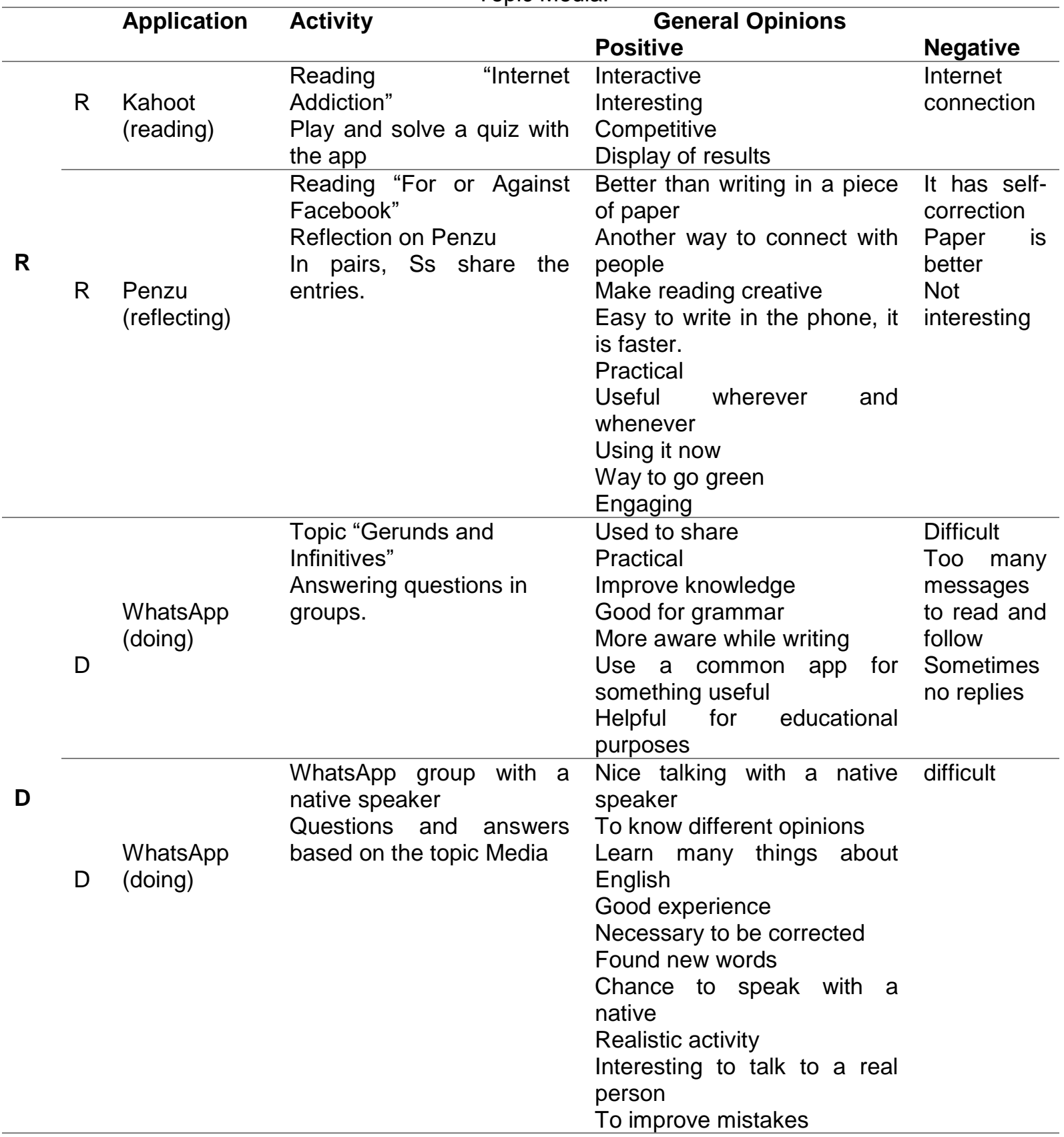

Source: Information taken from the instrument \#4 of the focal group I analysis. 


\section{Table 10}

Culture II Class.

Topic Holidays.

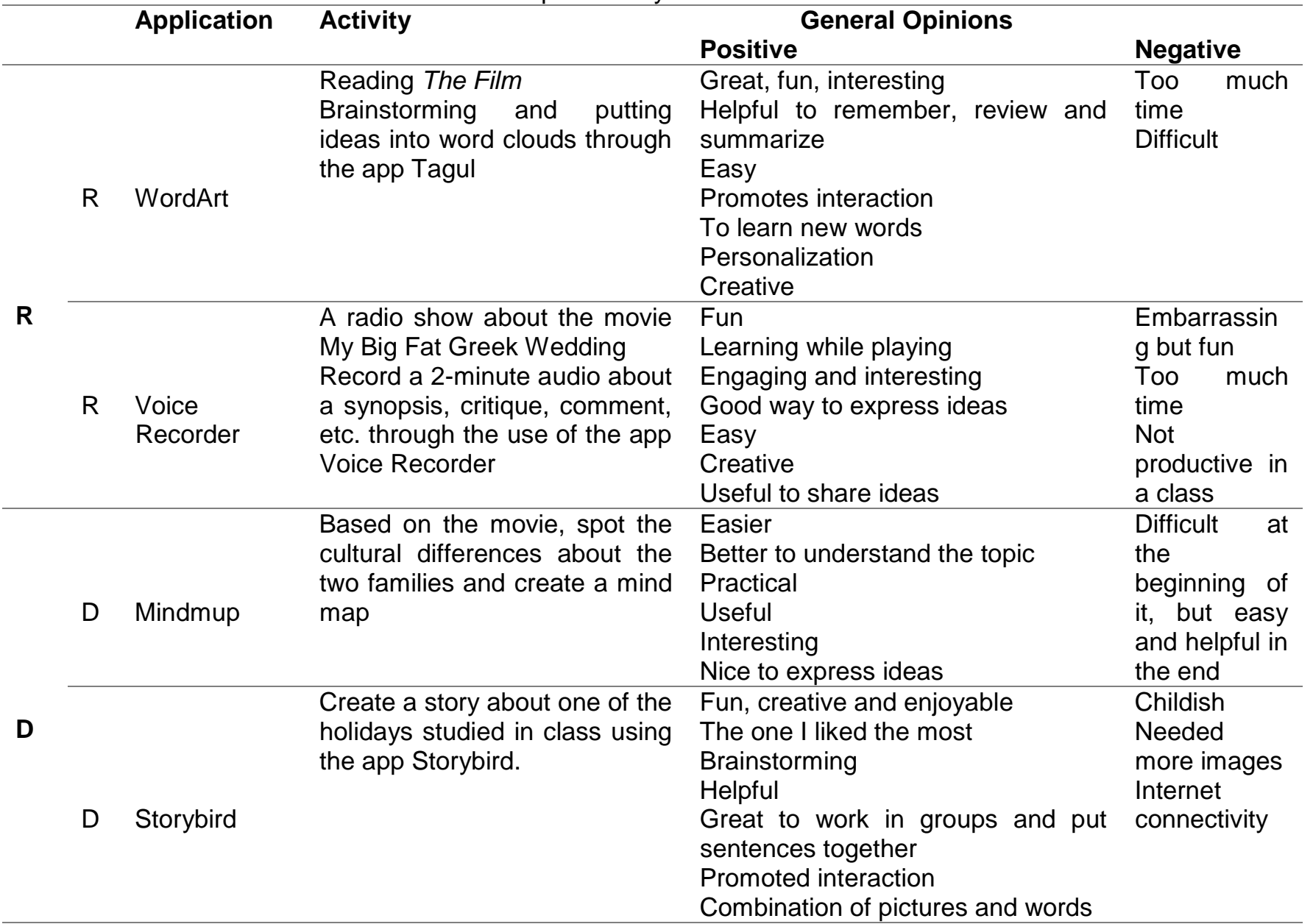

Source: Information taken from the instrument \#4 of the focal group II analysis.

The findings derived from the analyses of these data revealed that these freshmen and sophomore students embrace the activities that integrate technology. Some of them mentioned that they would like their teachers to continue using the applications with the model, and that they will keep using Penzu, WordArt, and Mindmup on their own. They confessed that even though WhatsApp is an everyday application, students were impressed by the pedagogical and innovative uses of it. Furthermore, they emphasized the importance of reducing the use of paper nowadays and use applications like Penzu to keep diaries, or like WhatsApp to type in their comments and submit them to the teacher (See Table 9). On this note, it is worth mentioning the fact that these two groups of students match the features of the millennials; that is, their ages and their "sophisticated knowledge of and skills with information technologies" (Bennett, Maton and Kervin, 2008, p. 779). 
For a great majority of the students, the applications were easy to use. Very few showed problems to use the apps. Following this line of thought, the population analyzed was willing to work, practice and learn the language using technology. Because of the students' openness and willingness to learn through the apps following the R2D2 model, they recommended teachers of other courses to use the apps and the model. Remarkably, learners pointed out actions like summarize, remember, brainstorm, work in groups, interact, and associate pictures to words as benefits stimulated by the performance of the activities through the use of the apps. Actually, these words can be related to the strategies upon which the R2D2 model is based.

\subsection{Limitations of the Study}

Since the nature of this research is limited to a particular group, the conclusions and results cannot be generalized to any other population. However, Thomas (2011) believed that if it is valid for this group, it might be generalizable to other cases and groups. Another limitation to this study can be the small size of the population. On this account, it is worth stating that the students of the groups deliberately chosen were the ones enrolled in the courses and whose teachers compromised and were willing to commit to all the phases of this research study.

\section{Conclusions}

After conducting an in-depth analysis of the literature and the findings of this study, the following conclusions can be drawn. To begin with, the R2D2 model through the implementation of a booklet of activities proved to be effective in various ways. Firstly, the data garnered from the predictive and the retrospective evaluation of the booklet of activities of the R2D2 model evinced the effectiveness of the model in all its stages. Indeed, the teachers highlighted the authenticity of the resources and the language included in the material and generated when performing the activities. Although the material presents simplified input, the teachers remarked that it does not affect comprehension of the texts.

It is worth noting that grammar structures and lexicon are internalized effectively through the presentation and use of valuable input. Images selected to illustrate the texts in the activities do not affect students' comprehension at all. On outcomes clarity, the R2D2 shows that the instructions and objectives are specific and clear, and the vocabulary given is suitable for students' linguistic level. Those two aspects foster rapid understanding, class 
engagement, and task-on attitudes. This model also gives the opportunity to provide input and feedback efficiently; teachers can decide what, when, and how to present the language to students, encouraging creativity and appropriateness depending on the context.

The material serves as a means to expand knowledge on different topics studied in class. In terms of procedures, this model boosts multiple task development, reasoning demands, and immediacy. Such a balance also provides students with opportunities to employ reasoning skills. Teachers also pointed out the encouragement of fluency and the production of lexically complex forms by the inclusion of immediacy in both levels: "here and now" and "there and then". Furthermore, the activities included in this model stimulates both fluent and accurate language as well as lexically complex production. The material stated the aims, the tasks met the objectives of the activities, and the instructions were clear. All in all, teachers asserted that the material that follows the R2D2 model ignites students' positive reactions towards it, it is accurate in terms of grammar, and in terms of the time spent for language used and gained; additionally, the time planned for the implementation of the material was sufficient, and the instructions were clear enough.

Secondly, the analysis of the information from the student questionnaire and the focal groups revealed very enlightening facts about the R2D2 model. According to students, the model contains innovative, worth-using, and authentic activities. It also promotes creativity, concentration and interest in reading tasks. It fosters engagement, teamwork skills, cooperation, interaction among students and opportunities to share ideas. Additionally, the model facilitates learning through picture-word association, it is easy to handle, and it gives a twist to ordinary apps such as WhatsApp. The findings evinced that the R2D2 model enhances learning strategies such as summarizing, brainstorming, visual associations and interacting with peers. It also promotes learning styles like auditory, visual and kinesthetic, and reinforces the activation of the multiple intelligences spatial- visual, verbal-linguistic, interpersonal, and intrapersonal.

Concerning the improvements derived from students' impressions and teachers' commentaries, it is worth pointing out the following aspects. First, the designers must check rigorously whether or not the comprehension of the texts is influenced by the images selected. Second, ideally, the designers must add a balance of cognitively simple and complex activities in all the stages of the model. Third, although the percentage of students that remarked this was low, designers must consider including more life-like activities in all the stages. Fourth, designers must evaluate the vocabulary according to the nature of the 
application; that is, if the application fosters oral production, the language selected must be aligned to it.

Fifth, some of the activities designed for each app must follow an analysis on possible drawbacks. For instance, for WhatsApp, designers must devise a strategy to regulate the overload of messages sent and to receive immediate feedback on time. Some students were discouraged to use the applications due to some factors like lack of confidence to interact with native speakers, in the case of the activity employing WhatsApp, and the level of difficulty to handle the app in the case of Mindmup. On this note, teachers must first boost students' confidence to talk to native speakers through some individualized strategies and teach students how to use the apps with enough time. Sixth, for the effective use of the applications and development of the activities, students need a strong Internet connection. Teachers using the model must check that first before implementing it. Seventh, designers must find the most suitable application to use with the groups after conducting a survey on learning styles to include in the stages of the R2D2 Model. Eighth, as a request from students, the researchers should ask the other faculty teachers to use the booklet in their classes.

\section{References}

Allen, I. Elaine and Seaman, Jeff. (2016). Online report card: Tracking online education in the United States. Babson Park, MA: Babson Survey Research Group. Retrieved from https://www.onlinelearningsurvey.com/reports/onlinereportcard.pdf

Ballester, Antoni. (2014). Meaningful learning in practice. Journal of Education and Human Development, 3(4), 199-209.

Becker, Henry Jay. (2000). Findings from the teaching, learning, and computing survey: Is Larry Cuban right? Education Policy Analysis Archives, 8(51). doi: http://dx.doi.org/10.14507/epaa.v8n51.2000

Bennett, Sue J., Maton, Karl A. and Kervin, Lisa K. (2008). The 'digital natives' debate: A critical review of the evidence. British Journal of Educational Technology, 39(5), 775786.

Bonk, Curtis and Zhang, Ke. (2006). Introducing the R2D2 model: Online learning for the diverse learners of this world. Distance Education, 27(2), 249-264. Doi: $10.1080 / 01587910600789670$

Collins, John and O'brien, Nancy. (2003). The greenwood dictionary of education. London: Greenwood Press. 
Costley, Kevin C. (2014). The positive effects of technology on teaching and student learning. Retrieved from https://files.eric.ed.gov/fulltext/ED554557.pdf

Ellis, Rod. (1997). The empirical evaluation of language teaching materials. ELT Journal, 51(1), 36-42.

Fitzpatrick, Anthony. (2004). Information and communication technology in foreign language teaching and learning -An overview. In Analytical Survey: Information and Communication Technologies in the Teaching and Learning of Foreign Languages: State-of-the-art, Needs and Perspectives (pp. 10-26). Moscow: UNESCO Institute for Information Technologies in Education.

Gall, Meredith D.; Gall, Joyce P., and Borg, Walter R. (2007), Educational research: An introduction (8th ed.). Boston: Pearson.

Hubbard, Philip (Ed.) (2009). Computer Assisted Language Learning: Vol 1 (Critical Concepts in Linguistics). London: Routledge.

Kubiatko, Milan. (2013). The comparison of different age groups on the attitudes toward and the use of ICT. Educational Sciences: Theory and Practice, 13(2), 1263-1272.

Larsen-Freeman, Diane and Anderson, Marti. (2011). Techniques and principles in language teaching. Oxford: OUP.

Lumpur, Kuala. (2016). Sampling methods in research methodology; how to choose a sampling technique for research. International Journal of Academic Research in Management (IJARM), 5(2), 18-27.

Lund, Andreas. (2004). Teachers as agents of change: ICTs and a reconsideration of teacher expertise. In Analytical Survey: Information and Communication Technologies in the Teaching and Learning of Foreign Languages: State-of-the-art, Needs and Perspectives (pp. 27-37). Moscow: UNESCO Institute for Information Technologies in Education.

Mısırlı, Zeynel Abidin. (2016). Integrating technology into teaching and learning using variety of models. IHEAD Ihlaraa Journal of Education, 1(2), 37-48. Retrieved from https://dergipark.org.tr/tr/download/article-file/397253

Mullamaa, Kristina. (2010). ICT in language learning: Benefits and methodological implications. International Education Studies, 3(1), 38-44.

Ramey, Deanna. (2016). 21 century teaching and learning. Young Children, 71(3). Retrieved from https://www.naeyc.org/resources/pubs/yc/jul2016/21st-century-teaching-learning

Robinson, Peter. (2003). The cognition hypothesis, task design, and adult task-based language learning. Second Language Studies, 21(2), 45-105. 
Sandeen, Cathy. (2008). Boomers, xers, and millennials: Who are they and what do they really want from continuing higher education? Continuing Higher Education Review, 72, 11-31.

Simons, Helen. (2009). Case study research in practice. London: SAGE.

Thomas, Gary. (2011). How to do your case study: A guide for students and researchers. Thousand Oaks: Sage

US Chamber of Commerce. (2012). The millennial generation: Research review. Washington: National Chamber Foundation.

Vasiljevic, Zorana. (2011). The predictive evaluation of language learning tasks. English Language Teaching, 4(1), 3-10. 
Revista indizada en

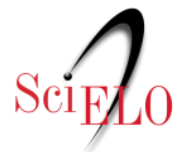

redalyc satindex

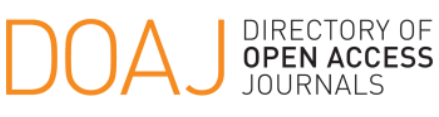

Distribuida en las bases de datos:

- Dialnet

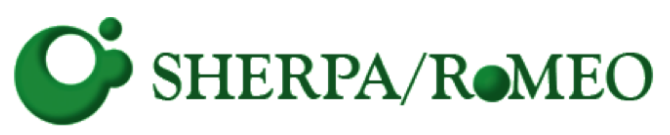

REDIB

Red Iberoamericana

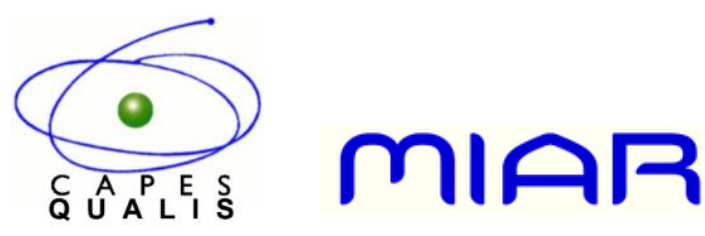

